\title{
On the Road in Latin America
}

\section{It is a new year and 2020 is now only four years away. For science fiction fans like me, it feels as if we have been transported by a time machine into the future!}

For the past month, I have been on the road in Latin America visiting Brazil (João Pessoa), Colombia (Bogota), Argentina (Buenos Aires), Chile (Santiago and Punta Arenas), and Uruguay (Montevideo). The continent is changing. There is more Internet access than ever before and mobiles are getting increasingly smart. In some places, the Internet penetration reaches more than $70 \%$. The academic community in many countries here has been immersed in the Internet since the late 1980s, but it is clear there is an awakening awareness of the utility of the Internet across the continent. Some of this can be attributed to the rapid expansion of mobile access through smartphones and some to the arrival of broadband services to the business community and, increasingly, residential settings. In Montevideo, for example, we tested wireless broadband speeds of $20 \mathrm{Mb} / \mathrm{s}$ down and 8-9Mb/s up just while driving around town.

While attending the Internet Governance Forum in João Passoa, Brazil, I had the pleasure of using an O3B ("Other Three Billion") ground station that delivered $400 \mathrm{Mb} / \mathrm{s}$ down and $100 \mathrm{Mb} / \mathrm{s}$ up in a hospitality tent adjacent to the conference facility. The system was installed in a few days and the model used was actually for shipboard applications requiring stabilizers for antenna tracking of the asynchronous, equatorial 8000KM orbit satellites.

I had the opportunity to meet with very senior officials in many of the countries I visited including President Michele Bachelet of Chile, newly elected President of Argentina Mauri- cio Macri, Vice President Raul Sendic of Uruguay and Simón Gaviria, Director of National Planning Development of Colombia. I met with regulators and with ministers or vice ministers of telecommunications, innovation, and information technology. Everywhere, I came away with a sense there is strong interest in Internet use in business, education, government services, and applications for the general public. Social networking uses are rising rapidly and, as in other parts of the world, smartphone applications are proliferating.

There were common themes in my many meetings: interest in domestic and global businesses facilitated by the Internet, analysis of conditions necessary for the creation and sustained growth of new business, curiosity and concerns for the way technology can disrupt old business models and challenge leaders to reinvent their companies. The future of print journalism and the arrival of Uber were topics that sparked much dialogue. Education was a common focus in every country. In Uruguay I met elementary school students, each of whom had a laptop computer (from the One Laptop Per Child program led by Nicholas Negroponte). Theywere using a mathematics program developed in Germany that allowed each student to progress at his or her fastest rate. When I asked about ideas for the future, one young boy said we should set up a center for ideas that can change the world - not a bad idea in itself! There is no question that every leader I met was fully aware of the importance of education at all levels to create and sustain old and new businesses.
Those of you who know me will be aware of my interest in wine and this little report about travel in Latin America would be seriously incomplete without an observation about the wines here. There are two that are particularly notable: Carmenere, of French origin, was largely lost in France in the mid-19th century and was rediscovered and nurtured in Chile more recently. Tannat is a varietal that was introduced in the late $19^{\text {th }}$ century in Uruguay and was new to me.

I had the opportunity to visit several vineyards and in particular the famous Concha y Toro vineyard in Chile where the flagship label is Don Melchor. Our party met with the wine maker, Enrique Tirado, and we prepared a unique cuvee from four-barrel samplings of cabernet sauvignon and cabernet franc. The variable dimensions of wine making rival any large complex program's space of variable values and my hat is off to the wizards of wine who produce consistent products year after year. In Uruguay, I was able to visit both the Bouza and the Juanico wineries and vineyards, both not far from Montevideo. It would be difficult to overstate the remarkable quality of the tannat grape and the blends that lend lush and round flavors that challenge the best cabernet sauvignons I have tasted.

From João Pessoa to Punta Arenas, this was a trip to remember, and to recommend to you as well. Happy New Year!

Vinton G. Cerf is vice president and Chief Internet Evangelist at Google. He served as ACM president from 2012-2014.

Copyright held by author. 